\title{
Os feminismos em Portugal
}

\section{O longo caminho das mulheres: feminismos 80 anos depois.}

AMÂNCIO, Lígia; TAVARES, Ma nuela; J OAQUIM, Teresa; ALMEIDA, Teresa S. de (Orgs.).

Lisboa: Public ações Dom Quixote, 2007. $470 \mathrm{p}$.

o livro reúne as comunicações a presentadas em um seminário que ocorreu em Lisboa, em maio de 2004, para celebrar o Congresso Feminista e da Educação rea liza do há exatos 80 anos. Mais do que um evento comemorativo, teve como propósito percorreros ca minhos traça dos pelos feminismos em Portugal desde os anos 20 do séc ulo XX a té a a tua lidade, buscando pensar suas diferentes formas de ação em função dos contextos políticos e sua contribuição para a modernização e democratização da sociedade portuguesa.
O livro foi organizado a partir de três eixos temátic os: "Feminismos e percursos", "Perfis das mulheres feministas" e "Feminismos na viragem do século XX". Este último é subdividido em cinco partes: "Os estudos sobre as mulheres e autoras feministas na vira gem do século", "Sexua lidades, corpos e feminismos", "Mulheres entre o públic o e o privado", "Violência sobre as mulheres" e "Ac ção feminista na vira gem do séc ulo". Encerrase, tal como aconteceu no Seminário, com a entrevista concedida por Maria de Lourdes Pintasilgo (1930-2004), primeira-ministra de Portugal (1979-1980) e candidata independente à Presidência em 1985.

O conjunto dos textos reúne temase autorias diversas: sã o 34 mulheres e três homens a assinar os diferentes artigos, o que acaba porconferir à obra um tom plural, a inda que seja consensuala referência ao movimento feminista como promotor de várias discussões de vanguarda no contexto da sociedade portuguesa, tanto na educação, quanto na medicina, na política, no mercado de trabalho, na ciência, entre outras áreas.

O primeiro eixo narra o percurso dos feminismos em Portugal e, em certa medida, no 
contexto europeu. A referência é o Congresso de 1924, identific ado como um acontecimento de grande importância para o movimento feminista. Organiza do pelo Conselho Nacional das Mulheres Portuguesas, fundado em 1914, o evento visibilizou as principa is reivindic ações das portuguesas daquele tempo: a obtenção do direito de voto (concedido de forma plena em 1974), dos direitos soc ia is e juríd ic os. A leitura dos textosque $o$ integram permite identific aralgumas inic ia tivas feministas existentes desde o iníc io do século $X X$, ta is como a criação do Conselho Nacional das Mulheres Portuguesas como uma a ssociação a ssumidamente feminista, a organização do I Congresso, a fundação da Associação das Mulheres Universitá rias de Portugal, as lutas em favor da co-educação, da a mplia ção dos direitos polític os, entre outras. Esse movimento foi, de certa forma, abortado pelo regime dita torial que se instalou a partir de 1926 com o govemo Salazar, cujo fim se deu com a Revolução dos Cravos, em abril de 1974. Ostextos perscrutam discursos e práticas desse perío do e relevam o pensamento conservador de a utorida des polític as, c ientífic as e religiosas para as quaisa representação hegemônic a da mulher é a da mãe, esteio da família e da sociedade. Assentados em explicações biológicas que a testa $m$ a ma ternida de como a tribuiçã o na tura do sexo feminino, os discursos que circulavam nesses tempos classificavam o feminismo como - princípio da ruína da família e, por conseqüência, do Estado. Nesse sentido, o recuo do movimento feminista português se deu pela opressão das forças políticas, o que, de forma a lguma, signific ou seu a niquila mento. Os textos mencionam diversas ações desenvolvidas pelas feministas nos meandros do cotidiano de um regime que condenava as vozes dissonantes ao silêncio.

O eixo "Perfis das mulheres feministas" na rra a trajetória pessoal e política de três feministas: Adelaide Cabete (1867-1935), médica, identificada como uma das precursoras do feminismo português; Maria Veleda (1871-1955), professora; e Maria Antónia Palla (1933-), jomalista feminista pioneira na imprensa diária na década de 50. A especificidade da atuação de cada uma delas é contada considerando o contexto polític o e cultural do tempo em que viveram, cuja proximidade se dá pela luta a favorda ampliação dos direitos das mulheres e em prol de uma sociedade menos desigual.

"Feminismos na viragem do século XX" constitui o terceiro eixo: volumoso e plural, é composto de cinco partes. Na primeira delas, um conjunto de seis textos foc a liza os "Estud os sobre as mulheres e autoras feministas na viragem do século". A pergunta "para onde vai este barco?" inaugura a sessão. Aqui se evidencia que, entre questionamentos, silenciamentos e visibilidades indiferentes, os feminismos foram traçando seus contomos em Portugal a través da criação de associações de mulheres e de espaços de produção e circulação do conhecimento. Revelam, entretanto, que, mesmo com o longo e sinuoso caminho trilhado, os estudos sobre mulheres ainda são, na maior parte das vezes, realizados por pesquisadoras que, a pesar de serem ma ioria na produção científica portuguesa, são poucas nos cargos de decisão. Outro foco de reflexões recai na discussão sobre as relações de poder que atravessam diferentes espaços socia is, seja entre homens e mulheres ou mesmo entre os distintos grupos de mulheres. São destacados os estudos da bióloga Anne FaustoSterling, que, ao afimar que os dados fixos da natureza podem ser manipulados pela cultura, faz ver que os disc ursos c ientífic os são a poia dos em pressupostos generificados.

$\mathrm{Na}$ esteira dessas críticas, os textos evidenciam a pluralidade do feminismo, cujos modos de pensar são diversos e constituíd os em vozes partilhadas, dissonantes, a proximadas, convergentes ou contraditórias, porém foc a liza das na s lutas e conquistas das mulheres. A noção de que "o pessoal é político" e a necessidade de compreender o funciona mento das estruturas de poder para ter condições de desa fiá-lo são recuperadasna proposição de um feminismo que toma as diferentes experiências e subjetividades das mulheres como o núcleo germinativo da construção de uma sociedade altemativa, sustenta da em tomo do partilhamento de lutas e preocupações dessa coletividade. As obras de Elisa beth Badintere de Donna Haraway são analisadas na perspectiva de evidenciar o caráter plural do feminismo do novo milênio, cujas proposições celebram um desloc arpermanente, o borramento de fronteiras, a implosã o de velhos a licerces, evocando a conquista da polifonia e da diferença.

"Sexualidades, corpos e feminismos" é composto portextosque discutem a emergência nos anos 60 das questões relacionadas à sexualidade feminina na sociedade portuguesa. Escla recem que a té a primeira meta de do século $X X$ a sexualidade era tratada pelo campo biomédico, área constituída por homens que usavam como padrão de referência a sexualidade e o corpo masculinos. Essa hegemonia foi rompida pelosfeminismos dosanos 
70 ao protagonizarem a luta das mulheres pela a propriação do seu corpo, em favor da contracepção e do aborto, reivindicando a vivência livre da sua sexualidade. São centrais, também, as a nálises sobre distintas formas de generificação doscorpose, no plano da política de identida de, as disc ussões a cerca das a lianças tecidas entre os movimentos lésbico, gay, bissexual e transgênero na luta pelos direitos das mulheres

O trabalho na vida de homens e mulheres e seus a tra vessa mentos com o públic o e o priva do também é tematizado nesse eixo. Os textos evidenciam o quanto as desigualdades entre homens e mulheres são alvo de intensos e acalorados debates. Ao mesmo tempo que a dualidade público-privado é questionada, há uma série de afirmações que a tribuem à legislação tra ba lhista portuguesa a manutenção das desigualdades, visto que, ainda hoje restringe direitos, suspende garantias e dificulta o acesso e a permanência de jovens mulheres no mundo do trabalho, em especial naqueles luga res to mados como masculinos.

A "Violência sobre mulheres" é abordada sob dois olhares finamente articulados: as reflexões teóric as e investig ações produzida s pelo feminismo, que permitiram criar as condições nec essá ria sà produção da visibilida de dos maustratos vividos pelas mulheres no interior de suas fa mílias e os rela tos de experiências de mulheres envolvidas no atendimento às mulheres vítimas de violência. Ambos destacam que, embora a legislação portuguesa possua certos a vanços quando comparada com a de outros países, ainda são poucas as mudanças observadas e interiorizadas no cotidiano, seja por questões cultura is, seja porfalta de medidas judic ia is que protejam as mulheres vítimas e punam os agressores.

O tema "Ação feminista na viragem do século" sublinha que o feminismo não é um estado de alma de algumas mulheres, mas sim um movimento para mudara sociedade. Poressa razão, é necessário potencializar suas capacidades, lutando para que a agenda política portuguesa abrace a igualdade entre homens e mulheres, sem prejuízos ou privilégios, como um direito fundamental.

Enfim, ao narrar trajetórias dos feminismos em Portugal o livro estende-se muito a lém da quele país. Sua leitura permite compreender que a história dos feminismos não é linear nem plena de positividades. Nela inscrevem-se a vanços e recuos, desistênciase persistências, possibilidades sempre negociadas consoante os tempos, as culturas, as representações, as práticas, os disc ursos. Permite, sobretudo, compreendermos que os direitos a dquiridos pelos feminismos não são garantidospara sempre, o que implic a etema vigilância e disposição para os enfrentamentos nec essá rios para sua a firmação.

Silvana Vilodre Goellner Universidade Federal do Rio Grande do

Angelita Alice Jaeger Universidade Federal de Santa Maria 